\title{
Administrative and Social Support Services for Students with Disabilities in the Selected Higher Education Institutions of Amhara Regional State-Ethiopia
}

\author{
Getachew Walelign Asres \\ MED in Special Needs Education, Special Needs and Inclusive Education Department, Faculty of Social Science \\ and the Humanity, Debre Tabor University, Ethiopia
}

\begin{abstract}
This study was conducted in universities found in Amhara regional state. There are 7 public universities in the region. One university was selected from each generation. Hence, Gondar was selected from $1^{\text {st }}$ generation, Wollo from $2^{\text {nd }}$ generation and Debre Tabor from the third generation universities. Qualitative case study design was used for this study. The participants of this study were students with disabilities, teacher, students without disabilities, special needs directorates, and library and students service coordinators. Four methods of data collection instruments were used to obtain valid and reliable information from different sources, and for the purpose of triangulation. The result showed that most students with disabilities obtained different administrative and social support services from universities. On the other hand, the findings showed that the actual support services provided for students with disabilities in the sample universities were not in line with its higher education proclamations. It is recommendation that the university should work more on the social accessibility and administrative support services given for students with disabilities.
\end{abstract}

Keywords: Social and administrative assistive services, students with Disability and Higher education institution DOI: $10.7176 /$ PPAR/9-1-03

\section{Introduction}

The higher education expansion and supportive education policy in the present Ethiopian context have opened a window the opportunity to increasing number of citizens with disabilities to benefit from higher education thus taking courageous move to tackle what Fuller et al. (2004) call invincible hurdle of higher education. The quest for equal and fair access is growing voice among students with disabilities, who successfully completed secondary education (Barnes, 2004). As noted in Putnam (2003), although access to persons with disabilities to higher education is slowly gaining momentum from time to time and from place to place, equality with regard to access has remained unattainable in most countries of the world including Ethiopia.

Millions of the people have some type of physical, mental or emotional condition that significantly limits their ability to function successfully in our society. In this case, there is no specific way to support students with special needs; instead, varying approaches of learning can have a better outcome for students with disabilities. Realizing the goal of successful education for students with special educational needs is not the task of the ministries of education and educational institution alone. It requires the co-operation of teachers, families, and the mobilization of the community and voluntary organizations as well as the support of the public-at-large. Therefore, the support services provided for students with disabilities are: academic by teachers, administrative, social, parental and peer (Dash, 2009, Kochung, 2011), If the students have the opportunity to get all the support services by these stakeholders, their academic, and social skills are enhanced.

The word accessibility can have different meanings for different people, for example: financial accessibility of services, Geographical accessibility, linked to the concept of local services, social accessibility in relation to the fight against stigma and psycho-sociological barriers (Handicap, International, 2009). Stinson and Antia (1999) define social accessibility creating conducive environment for students interact with others, make friends and accepted by peers and university communities. That is students with disabilities communicate in ways that are different from those around them and this can slow down their social interaction and development. Barriers that limit a person's full participation include; negative attitude, discriminative policies and practices, and inaccessible environments as a result of these barriers, students with disabilities are being excluded from accessing higher education. In addition, social support services directly related to promoting social initiations, relation and networks, values all students equally; higher expectation and increased inclusion in future environment (Getachew and Belay, 2001).

Administrative support is another important measure implementing for students with disabilities. This includes visiting of supervising students with disabilities; giving feedback to teachers for increasing their efficiency; financial assistance for implementing education for children with disabilities; constructions of resource rooms; maintenance of resource rooms; providing in- service education to teachers and the headmasters; deputing teachers to visit model special needs schools outside the state/ country and monitoring and evaluation of the program (Dash, 2009), For effective implications of students with disabilities, administrators are expected 
to be familiar with the concept, objectives and practices of special needs education in general and disability in particular. Such familiarity will help the administrator in supervision, monitoring, control and for providing leadership (English, 1993). Even when they visit institution, they do not give any specific feed back to the teachers about what they are doing and how they are doing. In such cases, the very purpose of supervision is lost. School expect financial assistance from the government to meet their contingency expenditure for purchase of aids and equipment, and other instructional materials, removal of architectural barriers and other environmental out comes modifications(Kenny, 2004).

Accordingly, very few students with disabilities receive higher education in Ethiopia. As long as, higher education was the preserve of privileged minority, the absence of students with disabilities was little noticed. The main obstacles to learning in Ethiopia are lack of information about diversity, rigid and poor curriculum, inaccessible learning environment, inadequate services, and inadequate assessment procedures, inaccessible building and infrastructure (Jung, 2003; Johnson, 2006). As a result, schools, universities and teachers find it difficult to accommodate students with special educational needs, and compel them to adapt to the school, instead of adapting to the need of the students (MOE, 2006). As many parts of the world including Ethiopia, this is still the case and where institutions of higher education purport to provide equal access, students with disabilities still face discriminatory policies and practices. To alleviate these problems in higher education institutions, the government of Ethiopia incorporated the provision of support services to students with disabilities in the two consecutive proclamations of higher education institutions which is launched in the year 2003 and 2009 respectively. (Getachew and Belay, 2012). These proclamations are

1. The Higher Education Proclamation №.351/2003. In this proclamation, there is a commence to protect the right of person with special needs. In this proclamation № . 351/2003 in its 3rd article (special support) sub article one proclaimed

Admission criteria or manner of acceptance set for female students, students with disabilities, students who have been completed with high school education in developing region may be different from others. They shall during their stay in the institution, special support and assistance services from the institutions.

2. The Ethiopian Higher Education Proclamation №. 650/2009 in its article sub article 1-4 proclaimed

Institution shall make to the extent possible their facilities and programs should be amendable to use with relative ease by physically challenged students. In addition, the document described that to the extent situations and resources permits relocate classes, develop alternative testing procedures and provide different educational auxiliary aids in the interest of students with physically challenged. Furthermore, building design, campus physical landscape, computers and other infrastructure of the institution shall take in to account the interest of physically challenged students and students with physically challenges get to the extent necessary and feasible academic assistance including tutorial sessions, exam time extensions and deadline extension.

Even if, the government of Ethiopia launched these two consecutive proclamations to assure the provision of support services for students with disabilities in higher education institution, the development of special needs education is very slow (Yared, 2008). Hence, research plays a pivotal role to examine the administrative and social support services provided for students with disabilities in Ethiopian higher education institutions.

As a result, assessing the administrative and social support services for students with disabilities and its challenges is valuable to design an effective and successful support strategy in order to address the diverse needs of all students with special needs in higher education institution. Despite a number of researches were carried out in relation to assessing the condition of support services in lower grades, scant attention is given on the condition of these assistive services in Ethiopian higher education institutions. Therefore, studying the actual administrative and social assisstive services provided for students with disabilities in universities is worthwhile for realizing their right of students to get support services and equalization between students with and without disabilities that our country is giving top most priority today. This initiated the researcher to conduct research on the area of assessing the administrative and social support services for students with disabilities in the context of higher institutions.

To this end; the researcher formulated the following leading questions:

1. Do students with disabilities have got administrative disability specific support services from higher education institutions?

2. Is the social environment of higher education institutions accessible for students with disabilities?

3. Is the current status of the provision of support services for student with disabilities in higher education institutions in line with its proclamations?

\section{Methods}

\section{Research Design}

The general objective of this study was to assess the administrative and social support services for students with 
disabilities in public higher education institutions. As a result, qualitative case study design was used for this study. Therefore, the study is based on a qualitative design approach which helps in showing the finer details of an issue and is more descriptive in its nature (Mertens 1998). This design is also widely applicable especially on those research that is conducted on special need education (Hartley, 2003). Thus, this research was conducted through in depth examinations of the provision of support services for students with disabilities.

\section{Study Site}

The study was conducted in higher education institutions found in Amhara regional state. There are 7 public universities in the region. These universities are divided as first (Bahir Dar and Gondar), second (Wollo, Debre Markos and Debre Berhan) and third (Debre Tabor and Woldia) generation. Therefore, this research was carried out on the sampled universities of each generation.

\section{Study Population}

This study was focused on all students with sensory (visual and hearing) and physical disabilities who have been attending their education in the selected universities. Therefore, the target population were all these students found in the sample universities (Debre Tabor from $3^{\text {rd }}$ generation, Wollo from $2^{\text {nd }}$ generation and Gondar from the $1^{\text {st }}$ generation).

\section{Inclusion Criteria}

This study includes all regular students with sensory (visual \& hearing) and physical disabilities who have been attending their education in different universities. I.e. the study included only students with visible and/or severe disability and those students who were easily accessible to the researcher

\section{Exclusion Criteria}

This study excluded those students with disabilities who were inaccessible to the researcher (summer, extension and evening students) that were attending their education in the universities. In addition, the study also excluded students with invisible disabilities (learning disability and communication disorder etc...)

\section{Participant of the study}

The participants of this study were students with severe disabilities; students without disabilities and teachers, special needs education directorate, library directorate, student's service coordinators (cafeteria and dormitory).

\section{Sample and Sampling Techniques}

Even if, the government of Ethiopia proclaimed higher education proclamations (i.e. admission criteria or manner of acceptance for students with disabilities, may be different from others) and practiced this proclamation, still the number of students with disabilities received higher institution is very low. Due to this reason, all students with severe disabilities in the selected sample universities and disability category were the informants of the study (interview and FGD). They were selected by using purposive sampling techniques.

Three student's directorate (1 from each university) and one (library, cafeteria, and dormitory) coordinator from each university (total of 9 participants) were also be selected as the informants of the study. All these samples were selected by using purposive sampling technique. This is because, the researcher believed that these informants had better information, and exposure about the administration, and social support services for students with disabilities. In addition, teachers of students with disability were also being the participants of the study. They were selected through convenience sampling technique. Whereas, the students' peers were selected by using snowball sampling techniques. Students with disability for FGD were selected using purposive sampling. That is, seven participants from each university who had better information about the support services given for students with special needs were involved in the discussion.

This is because in qualitative case study, it requires all these non-probability sampling techniques. As Gall, Gall and Borg (2007) stated, it is not possible to study everyone at the real life context in qualitative research methods. So, a qualitative study method requires a specific individual or group of individuals to gather detail information from them

\section{Data Gathering Instruments}

To gather authentic, genuine and accurate information about the condition of provision of support services from students with disabilities, their teachers, students without disabilities, special needs education directorate, library and students service coordinators (cafeteria and dormitory), four methods of data collection instruments were used to get rich information and for the purpose of triangulation. These include interview, observation, focus group discussion (FGD) and document review. 


\section{Methods of Data Analysis}

The data collected through different instruments like interview, observation, document review, and FGD were analyzed qualitatively. Qualitative analysis has been applied to the data obtained through all these instruments. Unquestionably, data analysis is the most complex and difficult of all the phases of a qualitative project (Fleury, 1993). Following the data collection through all verified instruments, analysis were made step by step. In order to make appropriate analysis, the collected data was at first presented in meaningful, organized and related manners so that the researcher could easily figure out the findings from each instrument to make the appropriate triangulation. Before the data analysis, the information that were gathered from the above sources were classified and organized by themes. Thus, the researcher were used cross case data analysis method. After these, conclusion were made and possible recommendations were forwarded.

\section{Ethical Consideration}

Disability research more than any other kind of research always requires ethical consideration at the forefront. Accordingly, the investigator has considered a number of measures to make his level best in keeping ethical issues in all stages of the study. Before gathering data from students with disabilities, their students with disabilities, teachers, directorate, the researcher asked permission from the universities and the above informants. Furthermore; the participants were told to them the significance and the purpose of the study.

Regarding the consent, the researcher was informed them that they can withdraw from participating in the research at any time and in any circumstance if they do not feel comfort. Moreover, tape recording was made with their due consent and knowledge. Pseudonyms were used instead of using real names during the data analysis. This is very important to make ethical considerations to gather better information from participants.

\section{Results}

\section{Background Information of Informants}

The total number of students with disabilities who have been attending their education in the sampled universities, the background of students with severe disabilities, students without disabilities \& teachers, special needs education directorate, library and students' service coordinators (cafeteria and dormitory) participated in the interview or/ and FGD are presented below

The total number of students with Disabilities attending their education in the sampled Universities

Table 1: The total number of students with disabilities who have been attending their education in the sampled university

\begin{tabular}{|c|c|c|c|c|c|c|c|c|c|c|c|c|c|c|}
\hline \multirow[t]{3}{*}{ No. } & \multirow[t]{3}{*}{ University } & \multirow{3}{*}{$\begin{array}{l}\text { No. } \quad \text { of } \\
\text { students } \\
\text { with } \\
\text { Disabilities }\end{array}$} & \multicolumn{12}{|c|}{ Types of Disability } \\
\hline & & & \multicolumn{3}{|c|}{ Visual } & \multicolumn{3}{|c|}{ Hearing } & \multicolumn{3}{|c|}{ Physical } & \multicolumn{3}{|c|}{ Unidentified } \\
\hline & & & $M$ & $F$ & Total & $M$ & $F$ & Total & $M$ & $F$ & Total & $M$ & $F$ & total \\
\hline 1 & $\begin{array}{l}\text { Debre } \\
\text { Tabor }\end{array}$ & 51 & 6 & 2 & 8 & - & 1 & 1 & 14 & 18 & 32 & 3 & 7 & 10 \\
\hline 2 & Gondar & 104 & 16 & 16 & 32 & - & - & - & 45 & 27 & 72 & - & - & - \\
\hline 3 & Wollo & 57 & 8 & 2 & 10 & 1 & 1 & 2 & 28 & 17 & 45 & - & - & - \\
\hline \multicolumn{2}{|c|}{ Total } & 212 & 30 & 20 & 50 & 1 & 2 & 3 & 84 & 62 & 149 & 3 & 7 & 10 \\
\hline
\end{tabular}

As it is depicted from the above table, the total number of students with different disabilities which have been attending their education in the sampled universities were 212. Of these, the larger number (104) constituted Gondar University (GC, Tewodros, Maraki, Fasil and Tseda campuses). These figures include both students with mild and severe disabilities. Among these, students with mild disabilities have been benefited from the preexisting regular educational approaches and the natural environmental conditions without any modification. Due to this reason, the researcher selected those students which have severe disabilities that need educational and environmental modification as an informant of the study (for interview and FGD.

\section{Background of students with disabilities who were participated in the Interview and FGD}

The total number of students with severe disabilities that were participated in interview and FGD from the sampled universities were 29 (9 from DTU, $10 \mathrm{GU}$ and $10 \mathrm{WU}$ ). Of these, the lion share constituted male students (22 in number). These students are placed in different faculties and departments. Furthermore, most students who have been attending their education in the sampled higher education institutions were students with physical disability and follow students with visual impairment. Besides, students with severe hearing impairment did not get the opportunity to enter higher education institutions. In addition, students with visual impairment were interested to attend their higher education in the social science streams, on the other hand, students with physical disabilities were from different departments and faculties. Mild students with disabilities were not included in the interview and FGD. 


\section{Background of Interviewees' Teacher}

Teachers who participated in the interview were from the different streams in which students with disabilities were found. In addition, most teachers who have been teaching students with different disabilities have two and above years of experiences. This long teaching experience helps the participants to provide genuine and real information about the conditions of support services in general and students with disabilities in particular. Besides, teachers taught these students in which different disabilities were found at different batches.

\section{Background of Special Needs Directorates}

As tried to obtained information form informants except one, the other informant directorates have 2 and above years of experiences in serving students with and without disabilities in the sampled universities. This long work experience helps the directors to provide reliable, detail and genuine information about the support services rendered for students with disabilities. As it is also indicated from the above table, most participants were females.

\section{The Background information of Library, Cafeteria and Dormitory Coordinators}

All the interviewed informants were taken from the three sampled universities. They had 3 and above years of working experiences in serving students with and without disabilities in different working centers (Library, cafeteria and dormitory) of the sampled universities.

\section{Background of Students without disabilities}

Students without disabilities were selected for interview from different streams in which children with different disabilities were found. These students knew their disabled peers in every aspect of their life and movements. For instance, some of them were support provider with recognized fees by the university, some were note readers and some were also classmates. This close relation that they had helps them to give detail, genuine, valued and reliable information about the administrative and social assistive services for students with disabilities inside and outside the classroom.

\section{Administrative Support Services}

Informants were asked about the administrative support services provided for students with disabilities by higher officials of the university. Almost all respondents agreed that students with disabilities were obtained different supports from administrators. For instance, all disabled and helpless students in all sampled universities have got 100 birr per month for keeping their personal hygiene. Respondents added that these students have been receiving stationary materials, modes for females, sanitation materials, assistive devices (slate, stylus, braille paper, cane, Dictaphone and wheelchair (not all universities)) .Crunch has been also provided for those students with lower limbs are impaired in collaboration with the nearby rehabilitation centers. Furthermore, case 3 during the interview mentioned that in addition to the provision of stationary and assistive devices, the university have been also providing different trainings for students with disabilities like study and life skills, job seeking skills, CV writing, entrepreneurship and social skills in order to empower students in all aspects of their life.

Special needs education directorate and students with different disabilities during the interview, and FGD disclosed that all students with disabilities have placed classrooms and dormitories in the accessible ground floors of the buildings. This clearly showed that administrators have been giving the greatest emphasis on students with disabilities. In addition to these, the participants described that students with disabilities also have got laundry and photocopy services from the university which was not provided for other students (especially at Gondar University and seldom in Debre Tabor University.). This is also assured by teachers Senit and Gedefaw during the interview. They explained that their department has been providing photocopy services peculiarly for students with disabilities.

Case 1 during the interview mentioned that the university administrators also strongly work with the surrounding community, Ethiopian telecommunication and NGOs like path finder to assist students with disabilities by contributing finance, modes, stationary \& sanitary materials and assistive devices. Students with disabilities also explained that university administrators supported them by providing special room for feeding in the cafeteria and reading room in the library to alleviate the challenges observed in the cafeteria and library service. As they said, the normal feeding rooms in the cafeteria have a slippery character. The nature of this feeding room is not conducive for students with crunch and cane users as well as others whose lower limbs are impaired. 

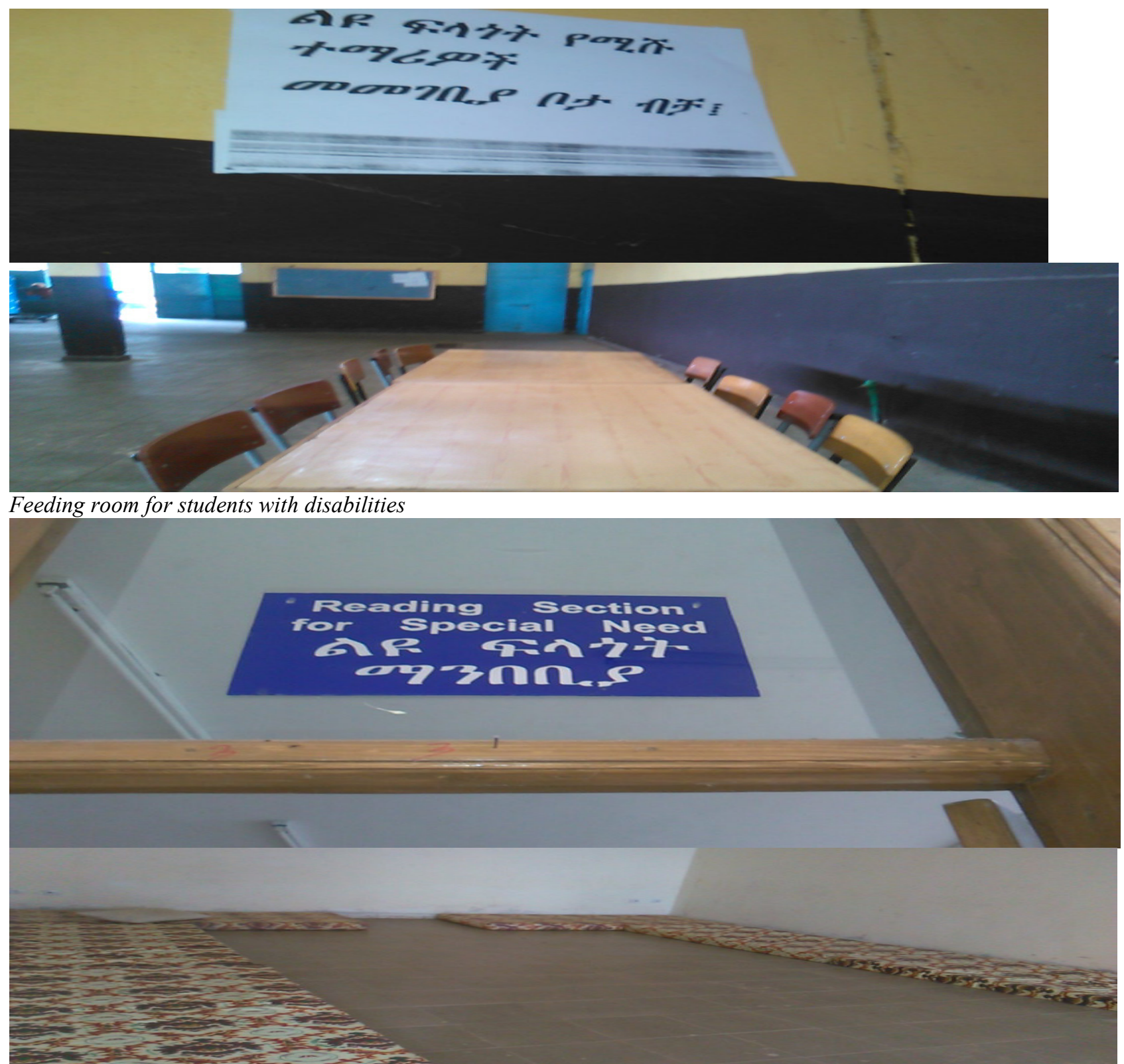

Furthermore, students and directorates repeatedly reported that graduated students with disabilities in all sampled universities have received 'graduation cloth from the university. This kind of special support services were not provided for other students including the poor. The data obtained from all informants also disclosed that the new freshman students with disabilities were allowed to enter in their interested departments. This means, the first department options were kept. They could join to those interested departments which were not given this chance for other freshman students. If the first department option was not even appropriate for them, again they had a chance to change after onwards.

Besides this, case 2 during the interview said:

10 special chairs were ordered to buy among others by considering the special problems of students with disabilities. In addition to this, special foam sponges were bought by the university administrators that used for students with physical disabilities while they read in the library.

This kind of service was not common to all sample universities. In the same vine, one university had assistive computer technology with JAWs software for students with visual impairment in one branch of the library (Wollo University). In addition, the department of special needs education set up resource center which has assistive computer technology with the above software (Gondar University). This resource center has been providing training and internet service for all students with disabilities found in the university. Two universities also established disability service center for the purpose of assisting students with disabilities found in all departments (Wollo and Debre Tabor University.) 


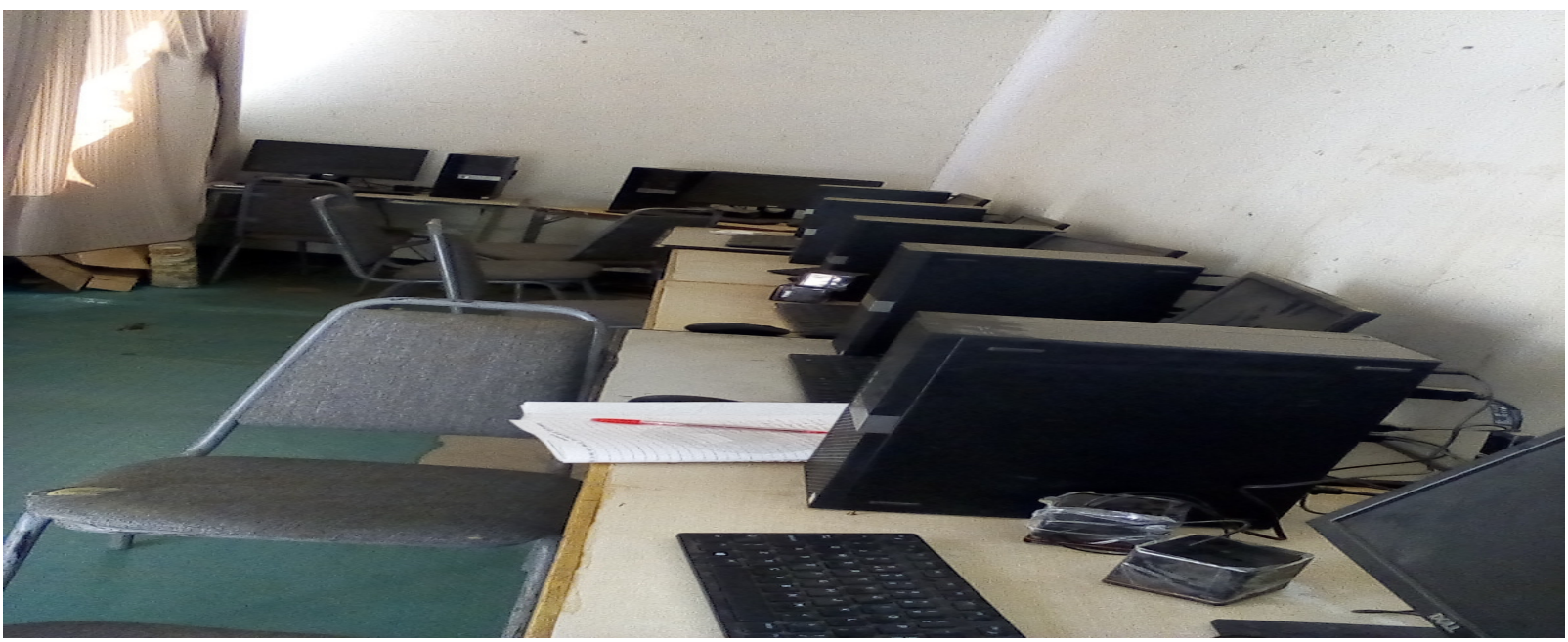

Internet room for students with special need at Wollo University

Regarding the availability of note takers, lab and library assistants, readers, and sign language interpreters, respondent teachers explained that universities did not have specially employed auxiliary aid provider for students with disabilities. Due to having this problem as case 1 described, the university referred deaf students to Addis Ababa University which has a sign language interpreter. Universities did not give due attention to have these professionals who gave support services for students with disabilities due to having low number of students with severe disabilities. To solve the problem of students with blindness and wheelchair users temporally, university administrators assigned their 'normal' peers in order to provide reading, guiding, and pushing wheel chairs services with low fees (Wollo and Gondar Universities). However, students during the interview and FGD reported that these support services are not sufficient.

The researcher also asked the informants about the supervision services provided; giving feedback to teachers and providing in-service teacher training. They responded that the university provided a supervision services to check whether the support services provided were effective or not. That is, whether students with disabilities were placed in the right dormitories and classrooms or not, whether they attended their education regularly or not; if teachers provided tutorial or not; if stationary and assistive services as well as pocket money were provided on time or not. In addition to these, the sampled universities did not provide in service teacher trainings in order to scale up teachers' knowledge and skills about disability education.

\section{Social Support Services}

The researcher asked the informants about the social assistive services provided for students with disabilities. Most participants responded that they took different services in order to create a social accessibility in the university. They further elaborated that the university prepared a well coming ceremony for freshman students for the purpose of valuing and creating a welcoming environment for students with disabilities in all sampled universities. For instance Belaynesh responded:

The university prepared a well coming ceremony for new entrant students. In this ceremony, senior students, special needs coordinator and disability club members gave counseling services and sharing their experiences about the university life. Moreover, in this ceremony, they advised us how to make friends with students with and without disabilities, and how to be effective in academic performances and social interaction. All these advices help me to make new friends and sustaining with them for a long period of time in the life of the university.

Student Sisay also explained as follow

The university was prepared a well coming ceremony for freshman students. This ceremony created a good opportunity for the present good social skills and academic success that I have. However, before the ceremony, my social relation was only limited with my disabled equals. After I entered in the university and participated in this ceremony, I got a good social skills and experiences. Now, I can communicate with the university community without problem.

In addition, most students with disabilities during the interview and FGD disclosed that different efforts were made by the university to create social accessibility for students with disabilities. Similarly, Case 3 during the interview remarked that different trainings such as life and study skills was provided for the purpose of creating a well coming social environment for students with disabilities. As she further explained, most students with disabilities have a problem in accepting their disabilities, giving low values for them and having poor social relations with others. That is why the university gave high intention in providing training for them to alienate these problems. In addition, disability club/ association members also provided advices and counselling services 
in collaboration with the special needs directorate in order to promote the social interactions of students with disabilities with teachers, students with and without disabilities and other staffs of the university.

The data gathered from special needs directorate indicated that library, cafeteria and dormitory workers have been taking training about how to give and improve their services to meet the diverse needs of all students in the university. Its purpose was creating social accessibility for students with disabilities with in these services giving centers. For example, during the interview, Case 1 explained

Some students with disabilities have low social skills. They were seen as facing problems to move in the campus without having guiders. Sometimes, they were absent in the class and exam time. This is because of having low social relations, they faced difficulties to get guiders. To solve this kind of problem, the directorate gives trainings for service giving center workers and assigned 'normal' peers to assist them in their study. This in turn helps them to scale up their social skills.

The researcher inquired students with disabilities about the social interactions that they had with their peers, teachers and administrative staffs (like cafeteria, library, dormitory, lounge etc.). Most participants responded that they had an excellent social relations with their peers and administrative staffs. Opportunities were created by the different levels of university officials to have had a good relations with them. For instance, during interview student Boru explained

The university assigned one 'normal' student as a support provider for assisting me in all aspect of my life. For example, he is a reader, a guider, a counselor and a sanitary. He is my model in every aspect of my life. I have learnt socialization with him. Now, I want to say I have a good social skills. I did not have this skill before the university life. Currently, I communicate simply with my class mates and university community without any difficulties.

Student Kasew mentioned that their normal peers had a positive attitudes towards them. Due to this reason, they could establish a good social relation with students without disabilities. In addition, students with disabilities have learnt different social cues in order to initiate socialization with the university staffs. During the FGD, students reported that they showed different sign and symptoms in order to be accepted by others. For example, show smiling face, talk common agenda, understand others' feelings and ask questions without fear to establish social relations. All these social skills were learnt in different trainings given by the university .However, some students remarked that they could not create social relations with some administrators and teachers. For example, one student during the interview strongly mentioned:

We collected our problems and asked higher administrators of the university to give immediate solutions to our serious problems. Higher officials said that these kind of problems will be solved through time and these kinds are not considered as a problem for us. They further said, you are the lucky person in the university, because at least you have got food. They also said that your equals did not find this opportunity, and they lead their life by begging at the street outside the campus. At this time, we did not feel we are equal with others and after onwards we are not interested to make social relations with them. This kind of sayings affect our psychological feeling.

In the same vein, other student during the interview explained that teachers did not give equal value for all students in the classroom. They assumed that students with disabilities could not do classroom instructions like that of 'normal' peer. They said for instance "Do you have an ability to do this activity" This kind of speech underestimates students with disabilities. Another student during the interview also disclosed that most of the time teachers believed that students with disabilities could not perform their subjects like the 'normal' peers. They considered them as weak, dependent and lazy. He further explained as "this university is not appropriate for you and this course is difficult for "normal' students and it is even too difficult for you)" All these evidences clearly show teachers do not address diversity and give value for all students in the classroom.

On the other hand, there were some higher officials, and teachers who appreciates, values and address diversity in the university. For instance, Bega during the discussion explained that administrators including the president and vis presidents have a positive attitudes towards students with disabilities. They gave high values and solving their problems immediately. .Besides, there were some teachers who care students with disabilities especially in the usage of classroom language in order not to affect their psychological feeling.

The Assistive Services in Comparison with the Higher Education Proclamations

Box 2: The Ethiopian Higher Education Proclamations that address students with Disabilities Proclamation NO. 351/2003, 3rd article (special support) sub article one

$>$ Entry assessment or admission procedure designed for any female, disabled student, a student who has completed high school education in a developing Region or who is native of the nationality of such Region or a student from the nationality whose participation in Higher Education is low shall be different from others. They shall, during their stay in the institution, get special supports; particulars of such support shall be determined by the Ministry.

$>\quad$ Notwithstanding the provisions of Sub-article (1) of this Article education for the dumb and deaf may be 
given in a sign language.

Proclamation NO. 650/2009 in its article sub article 1-4

$>$ Institutions shall make, to the extent possible, their facilities and programs amenable to use with relative ease by physically challenged students.

> Institutions shall, to the extent that situations and resources permit, relocate classes, develop alternative testing procedures, and provide different educational auxiliary aids in the interest of students with physical challenges.

$>$ Building designs, campus, physical landscape, computers and other infrastructures of institutions shall take into account the interests of physically challenged students

$>$ Institutions shall ensure that students with physical challenges get to the extent necessary and feasible academic assistance, including tutorial sessions, exam time extensions and deadline extensions.

$>$ Education for students with complete hearing impairment shall be given in or supplemented by appropriate sign language

Source: Federal Negarit Gazeta of the Federal Democratic Republic of Ethiopia. 9thYear No. 72, Addis Ababa3rdJuly 2003 and 15th year no. 64 Addis Ababa 17th September, 2009

Students with disabilities should have equal opportunities to participate in higher education as well as students without disabilities. These opportunities are mentioned in a number of various international and national legal documents within a growing attention. Hence, The FDRE was launched two higher education proclamations in the year 2003 and 2009. In these proclamations in its article 3(2003 proclamation) and sub article 1-4(2009 proclamation) gave due emphasis on the provision of support services and accessibility for students with disabilities. Thus, in this part, the researcher tried to analyze the actual support services provided for students with disabilities by the university in relation to its consecutive proclamations of the higher education institutions. It analyzes as follows:

1. Entry assessment or admission procedure designed for ......., disabled student, shall be different from others. This sub article of the proclamation has been practicing by all sampled universities. Although the admission criteria/score for disabled students to higher education were different from year after year, they entered higher education with lowered admission score in comparison with students without disabilities.

Table 2: Comparison of university entrance point/ score in Ethiopia (NEAEA) between students with "Normal" and students with disabilities

\begin{tabular}{|c|c|c|c|c|c|c|c|c|c|c|c|c|}
\hline \multirow[t]{4}{*}{ No. } & \multirow[t]{4}{*}{ Year } & \multicolumn{4}{|c|}{ 'Normal'students } & \multicolumn{7}{|c|}{ Students with disabilities } \\
\hline & & \multirow{2}{*}{\multicolumn{2}{|c|}{ Social }} & \multirow{2}{*}{\multicolumn{2}{|c|}{ Natural }} & \multirow{2}{*}{\multicolumn{2}{|c|}{$\begin{array}{l}\text { Hearing } \\
\text { impaired }\end{array}$}} & \multirow[t]{3}{*}{ Blind } & \multicolumn{4}{|c|}{ Pastoral special needs } \\
\hline & & & & & & & & & \multicolumn{2}{|c|}{ Social } & \multicolumn{2}{|c|}{ Natural } \\
\hline & & $\mathrm{M}$ & $\mathrm{F}$ & $\mathrm{M}$ & $\mathrm{F}$ & $\mathrm{M}$ & $\mathrm{F}$ & & $\mathrm{M}$ & $\mathrm{F}$ & $\mathrm{M}$ & $\mathrm{F}$ \\
\hline 1 & 2015 & $280+$ & $270+$ & $315+$ & $300+$ & $300+$ & $300+$ & $270+$ & $270+$ & $270+$ & $300+$ & $300+$ \\
\hline 2 & 2016 & $335+$ & $320+$ & $352+$ & $330+$ & 297 & 275 & $200+$ & - & - & - & - \\
\hline 3 & 2017 & $330+$ & $320+$ & $354+$ & $340+$ & 275 & 275 & $200+$ & $315+$ & $300+$ & $320+$ & $305+$ \\
\hline
\end{tabular}

Ethiopia university entrance point. Sources: https/www.ese tub.com, https/www.esetube/Ethiopia and dire tube

As it is depicted in the above table, the admission score of students with disabilities are lower than when we compared to that of students without disabilities.

In addition in this sub article, the proclamation further stated that students with disabilities shall during their stay in the institution, get special support; particulars of such support shall be determined by the Ministry. In this sub article, the proclamation did not clearly state in detail like what kind of support services shall be provided for students by the institution. Due to this reason, universities have been providing different support services for different categories of disabilities as they could base on their knowledge and interpretation.

2. .... education for the dumb and deaf may be given in a sign language. When we see the actual practice of these sub articles of 2003 and 2009 proclamations, the researcher assured that there is no severely hearing impaired students found in the sampled universities that need sign language experts. Due to having this reality, there were no sign language interpreters employed by the university for this purposes. However, Debre Tabor University referred two deaf students to Addis Ababa University which was admitted to the university in this year, because of unavailable of sign language interpreters in the classroom.

3. .....to the extent possible, their facilities and programs amenable to use with relative ease by physically challenged students. For this sub article, the researcher assured that students with different types of disabilities did not benefit from this sub article of the proclamation. Universities in general and teachers in particular did not amend and modify exam \& class schedules and other programs to students with disabilities. For instance, Neges during the discussion explained as

When class exam and other university programs were scheduled by the university, they considered majority students found in the classroom. No program is modified or accommodated by considering 
students with disabilities. We also did not ask this issue, because we know that the program was not amendable for students with disabilities. Sometimes, when students with disabilities delayed during the exam as a result of their disability, teachers are not happy.

This evidence clearly showed that the programs, and schedules set by the university were not being flexible to satisfy the divers' problems, and needs of students with disabilities in higher education institutions.

4......resources permit, relocate classes, develop alternative testing procedures, and provide different educational auxiliary aids in the interest of students with physical challenges.

The data gathered from different informants clearly showed that students with disabilities were attending their education in a conducive classroom (in terms of location). That is, they have been attending in the ground floors of the buildings. The same is true in their dormitories. This indicated that this part of the sub article is practiced in all sampled universities. However, as data collected from interview and FGD, teachers did not prepare an alternative testing procedures to address the diverse needs of students with disabilities. In addition, the university did not employee professionals (sign and braille language) in providing different educational auxiliary aids in the interest of students with disabilities.

5. Building designs, campus, physical landscape, computers and other infrastructures of institutions shall take into account the interests of physically challenged students

In relation to this sub article, observation, interview and FGD results showed that all buildings in the sampled universities were not constructed by considering students with disabilities. They do not have ramps, bridges and elevators. Ramps were reconstructed currently in a few buildings by the constant suggestions provided by special needs directorate in collaboration with the building design and development directorate of the university. Moreover, the campuses, infrastructure of the university and its land scape were inaccessible for students with disabilities. The natural environment are ups and downs and its roads were not constructed by considering wheelchairs and cane users.

Hence, it is possible to say, this sub article is not practiced in all the sampled universities.

6 ...... students with physical challenges get to the extent necessary, and feasible academic assistance, including tutorial sessions, exam time extensions, and deadline extensions.

As it is described above, students with disabilities have got some academic assistances services from their 'normal' peers. However, except some, most teachers did not provide these services for students with disabilities. That is, they did not give tutorial and adapt their instructions according to the multiple needs of all learners in the classroom. Furthermore, the university teachers did not make any amendment on class, exam and deadline extension to address diversity in the classroom. All these evidences showed that this sub article is not properly implemented.

\section{Discussion}

As it is stated previously, the purpose of this study was to assess the provision of support services for students with disabilities in higher education institutions. There for, the results of the major findings in relation to the research questions, and review of related literature were discussed and interpreted. Hence, the provision of academic, administrative and peers support services; the accessibility of the physical and social environment; the status of support services in relation to the higher education proclamations, and its challenges were discussed in comparison with other research findings.

Review of related literature indicated that differentiation of teaching is basically necessary to help students with disabilities acquire real-life skills and to help them continue their education in harmony with students without disabilities in the same learning environments (Tomlinson, 1999, 2001; Tomlinson, Kaplan, Renzulli, Purcell, Leppien and Burns, 2002). This includes, modifying/ adopting the curriculum to suit to the needs of special needs; flexibility and improving teaching; modifying method of teaching, assessment techniques, activities and schedules. However, the result of this study revealed that most students with disabilities did not obtain a special academic support services from teachers. That is, no adapted curriculum alignment and innovative practices were made; no special tutorial given; no modification was made on the different instructional activities.

The research found out that students with disabilities were obtained different support services from administrators. For instance, all disabled students in all sampled universities have got 100 birrs per month for keeping their personal hygiene. The results also showed that students have been receiving stationary materials, modes for female students, sanitation materials, assistive devices (slate, stylus, braille paper, cane, and crunch), laundry, and photocopy services, Dictaphone and wheelchairs. Supporting this, Bretz, (2000) stated the necessity of ensuring students with disabilities, by means of assistive learning materials as contributory factor to accessibility of education for those enrolled in higher education institutions. The materials include textbooks, modules, digital materials, audio and video materials; Braille texts, computers and accessories and the like materials are supportive to learn alongside their peers at colleges. The finding of the study also identified that universities provided different trainings for students with disabilities like study and life skills, job seeking skills, 
CV writing entrepreneurship and social skills in order to empower students in all aspects of their life. In addition, university administrators supported them by providing special room for feeding in the cafeteria and reading room in the library to alleviate the challenges observed in the cafeteria and library service. Contrary to this, literature showed terribly poor and limited quality of services in the universities covered provided by the administrator (IDEA, 1997; Kenny, 2004)). Higher education accessibility barriers including physical, architectural, service deliveries, provisions of learning materials and equipment, attitudinal and cultural influences.

The finding of the study revealed that universities have special needs coordinator at a directorate level in the organizational structure of the university. Contrary to this finding, HEATH (1999) study showed that the absence of any kind of disability support staff in the Ethiopian institutions, most public and all private institutions reported that they do not have a disability officer/coordinator or advisor. Moreover, all students with disabilities have placed classrooms and dormitories in the first floors of the buildings. Stinson and Antia (1999) explained that disability prevents someone from doing what they want or need to do. It needs to evaluate whether the classroom is effective for wheelchair users or not, as long as has access to the dormitories and the library, as well as to whatever other places and material or equipment that are necessary for students with disabilities to do their job well. Besides, graduate students with disabilities in all sampled universities have received 'graduation cloth' from the university.

However, the administrators did not supply special auxiliary aid provider for students with disabilities like sign and braille language expertise. Literature on this area also identified that most students with disabilities had encountered barriers to their education, including a lack of understanding and cooperation from administrators, faculty, staff and other students; lack of professionals and other accommodations; and inaccessibility of buildings and grounds (English,1993).

With respect to the social accessibility for students with disabilities, the finding indicated that the university prepared a well coming ceremony for freshman students for the purpose of appreciating differences and creating a welcoming environment for students with disabilities in all sampled universities. For instance Belaynesh responded that the university prepared a well coming ceremony for new entrant students. In this ceremony, she has got an opportunity to make friends with her with and without disabilities and to be effective in her academic performances and social interaction. Anderson (1993) arrived essentially as the same conclusion. He described the social support network as important for students with disabilities to successful to academic and social adjustment to university.

The researcher also identified that different trainings such as life and study skills were provided for the purpose of creating a well coming social environment for students with disabilities. Supporting this, Collins (1995) explained that their relationship with the university is not limited to academic education but also to preparation for life beyond the classroom. Building confidence and the necessary social skills of students with disabilities is of equal priority to the necessary academic skills that prepare people to meet future challenges. In addition, disability club/ association members also provided advices and counselling services in collaboration with the special needs directorate in promoting the social interactions of students with disabilities with teachers, students with and without disabilities and other staffs of the university. Emphasizing at this point, Stinson and Antia (1999) described that social accessibility creating conducive environment for students interacts with others, make friends and accepted by peers and university communities.

The data also showed that library, cafeteria and dormitory workers have been taking training at every year for improving their services to meet the diverse needs of all students in the university. Its purpose was creating social accessibility for students with and without disabilities in these service giving centers. In relation to this, Getachew and Belay(2001) noted that the social support services directly related to promoting social initiations, relation and networks, values all students equally; higher expectation and increased inclusion for creating social accessible environment.

Furthermore, their normal peers had a positive attitudes for students with disabilities. Students with disabilities have learnt different social cues in order to initiate socialization with the university staffs. All these social skills were learnt in different trainings given by the university. In relation to this, Stinson and Antia (1999) described that social accessibility is the ability to interact with, make friends with and accepted by peers.

The finding also revealed that there were some higher officials and teachers who appreciates, values and address diversity in the university. For instance, Bega during the discussion explained that administrators including the president and Vis presidents have a positive attitudes towards students with disabilities. They gave high values and solving their problems immediately.

However, some students remarked that they could not create social relations with some administrators and teachers. The result also revealed that teachers did not give equal value for all students in the classroom. Most of the time, teachers believed that students with disabilities could not perform their subjects like that of the 'normal' peers. They considered them as weak, dependent and lazy. This kind of perception leads students with disabilities to be isolated from university staffs and their peers. Previous research findings also advocated this finding, for instance, Tirussew (2005) noted that regarding undermining attitude in the Ethiopian context, 
indicated persons with disabilities are perceived as "weak", "hopeless", " dependent", and "unable to learn" and "subject of charity". The misconceptions of causal attribution added to the misunderstandings of the capabilities of persons with disabilities have contributed to the low social and economic statues of persons with disabilities.

The research findings also showed that except one, the support services for students with disabilities indicated in the higher education proclamations were not fully implemented in the sample universities. Yared, (2008.) arrived the same conclusion, he explained that some countries in Africa has made progress in introducing disability related legislation, but many of these laws have not yet been implemented. Hence, the first sub- article that is the 'entry assessment or admission procedure designed for disabled student in higher education shall be different from others..... is practiced in all sample universities. Thus, this practice is in line with this sub article. Supporting this, UNESCO (1999) study showed that with regard to admission procedure, the university was following an affirmative action for disabled students in Ethiopia.

\section{Conclusions}

The purpose of this study was to investigate the administrative and social assistive services given for students with disabilities in the selected higher education institutions of Amhara regional state. The data collected through different instruments from various informants were analyzed qualitatively. Based on the findings of the research, the researcher has reached the following conclusions

1. The administrator provided different support services for students with disabilities. That is, they provided financial, stationary materials, modes, sanitation materials, assistive devices, laundry and photocopy and trainings services. However, they did not provide special auxiliary aids for students with disabilities such as sign and braille language professionals.

2. The university took different activities in order to create a social accessibility for students with disabilities by celebrating a well coming ceremony for freshman students, providing trainings for students and staffs, establishing disability club and developing positive attitude to students with disabilities.

3. Except the admission criteria, the support services for students with disabilities indicated in the higher education proclamations were not effectively implemented in the sample universities.

\section{Recommendations}

Based on the findings of the study, the following major recommendations were forwarded:

1. The university should employee special needs education professionals in order to decide the students' eligibility for different supports and related services and provide sign and braille language translations for students with sensory disabilities inside and outside the classroom.

2. The university staffs should know the higher education proclamations set by FDRE and implement its sub articles that give due emphasis on the support services provided for students with disabilities accordingly.

3. The MOE should evaluate and comment the social accessibility of the university for students with disabilities while it is under construction in relation to the building proclamation of Ethiopia.

4. The university should develop specific rules, regulations and guidelines that used to guide the provisions of support services for students with disabilities.

5. Further research needs to be conducted on the provision of support services for each category of students with disability separately in higher education institution in Ethiopia. (i.e. Visual and hearing impairment, physical disability, health impairment, learning and communication disorder.)

\section{References}

Anderson MPI (1993). Social support and barriers to post-secondary education: Experience of students with physical disabilities. Unpublished master's thesis, University of Alberta at Edmonton, Canada

Barnes, C. (2004). Disability: Disability Studies and the Academy. In J. Swain., S. French, C.

Bretz, R., \& Johnson, L. (2000). An innovative pedagogy for teaching and evaluating computer literacy. Information Technology and management,

Collins KD (1995). A model of college adjustment for students with physical disabilities. Unpublished doctoral dissertation, University of Illinois at Urbana-Champaign.

Dash, N. (2009). Support Services for Children with Special Needs in the State of Sikkim Lovely Professional University, Phagwara, Punjab,India. Anuradha Rai, Research Scholar, Deptt of Education, Lovely Professional University, Phagwara, Punjab.

English KM (1993). The role of support services in the integration and retention of college students who are hearing-impaired. Unpublished doctoral dissertation, Claremont Graduate School and San Diego State University

Fuller, M., Healey, M., Bradley, A., Hall, T. (2004). Barriers to Learning: a systematic study the experience of disabled students in one university. Studies in Higher Education,

Gall, M.D., Gall, J.P \& Borg, W. R. (2003). Educational Research an Introduction (7th Ed.). New York: Pearson 
Education, Inc.

Getachew, W and Belay, S. (2012). Special Needs Education (complied). A module for the Course special Needs Education for Linear Program Students. Unpublished.

HEATH (1999). Creating options: A resource on financial aid for students with Disabilities. Washington, DC: George Washington University, Graduate School of Education and Human Development. URL: http://www.heath.gwu.edu/PDFs/2003\%20Finaid\%20Document.pdf (retrieved on 10, January, 2017).

Handicap International. (2009). Accessibility: How to Design and Promote an Environment Accessible to All? Vassel Graphique printing: press

Hatch, T. (1998). How comprehensive can Comprehensive Reform be? Phi Delta Kappan. 79. 518-522

Individuals with Disabilities Education Act (IDEA), (1997). Retrieved on November, 2017,

Johnson

Johnson, A. L. (2006). Students with disabilities in postsecondary education: Barriers to Success and implication to professionals. Vistas Online. Retrieved August 31, 2017, From http://counselingoutfitters.com/vistas2006

Jung, K. E. (2003). Chronic illness and academic accommodation: meeting disabled "Unique needs" and preserving the institutional order of the university. Journal of Sociology and Social Welfare, 30(1),

Kenny, M. (2004). Postsecondary students with disabilities and perception of faculty members. The Journal for Vocational Special Needs Education

Kochung, E. (2011). Role of Higher Education in Promoting Inclusive Education: Kenyan Perspective

Mendez, G. (1998). The Effect of Teachers' Perceived Self- efficacy, Beliefs and Subsequent Behaviors and Support for Research Based Effective Teaching Behaviors on their Attitude toward Children with Special Needs: Implications for Inclusive Education. Dissertation Abstract International. URL: www.lib.umi.com/dissertations/search.

Misrak Tarekegn (2006), Challenges and opportunities of access and mobility in Addis Ababa; the case of people, with motor and visual impairments, Publisher Addis Ababa University School of Graduate Studies http://www.rrtc.hawaii.edu/products/phases/phase2 02.asp?studyNumber

MOE (2006). Special Needs Education Program Strategy: Emphasizing Inclusive Education to Meet the UPEC and EFA Goals. National Report. Addis Ababa.

President Obama. (2014). Supporting Individuals with Disabilities. The President's fiscal year 2014 budget request in education Report. Washington` DC.

Putnam, M., Geenen, S., Powers, L., Saxton, M., Finney, S., \& Dautel, P. (2003). Health and

Wellness: People with disabilities discuss barriers and facilitators to wellbeing. Journal of

Stinson, M. and Anita, S. (1999). Considerations in Educating Deaf and Hard of Hearing Students in Inclusive Settings. Journal of the Deaf Students and deaf Education, 4, 163-175

Tirussew, Tefera..(2005).Disability In Ethiopia: Issues, Insights and Implications. Addis Ababa: Addis Ababa University Press.

Tirussew Teferra (1994). Psychosocial and Educational Problems of Students with Disabilities in Addis

Ababa University. Ethiopian Journal of Health Development Vo.8, No.1, 1994.

Tomlinson, C. A. (1999). The differentiated classroom: Responding to the needs of all learners. Ascd. Retrieved September 24, 2017 from http://classroom.leanderisd.org/users/3748/docs/what_is_differentiation.pdf

Tomlinson, C. A., Kaplan, S. N., Renzulli, J. S., Purcell, J., Leppien, J.,\& Burns, D. (2002). The parallel

Curriculum: A design to develop high potential and challenge high-ability learners. Thousand Oaks

The Federal Democratic Republic of Ethiopia. (2009). Federal Negarit Gazeta. Higher Education Proclamation NO. $650 / 2009.15^{\text {th }}$ Year No. 64 Addis Ababa 17th September, 2009

The Federal Democratic Republic of Ethiopia. (2009). Federal Negarit Gazeta. Ethiopian Building Proclamation No. 624/2009. 15th Year No. 31 Addis Ababa 6th May, 2009

The Federal Democratic Republic of Ethiopia. (2003). Federal Negarit Gazeta. Higher Education Proclamation no. 351/2003. $9^{\text {th }}$ year no. 72 , Addis Ababa-3 ${ }^{\text {rd }}$ July, 2003.

United Nations. (2006). Convention on the Rights of Persons with Disabilities -New York: United Nations. URL: http://www.un.org/disabilities/convention/conventionfull.shtml [11 Jan. 2018]

UN. (1983). World Program of Action Concerning Disabled Person. New York.

UNESCO (1999). Provision for Students with Disabilities in Higher Education. The UNESCO Section for Special Education. 